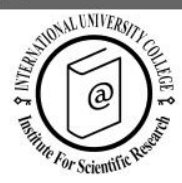

\title{
How do Motivation, Pre-Visit Information Search and Destination Image affect Post-Visit Behavioural Intention? The case of an island destination
}

\author{
Li-Hui Chang ${ }^{1}$, Nikolaos Stylos ${ }^{2}$, Shih-Shuo Yeh $^{3 *}$ and Yu-Yun Tung ${ }^{4}$
}

Received: 20/12/2013 Accepted: 24/04/2014

\footnotetext{
Associate Professor, Department of Tourism Management, National Quemoy University, 1University RD., Jinning Township, Kinmen, Taiwan, Email: lisali@nqu.edu.tw, Phone: +886935455066

Lecturer in Marketing, Department for Marketing, Innovation, Leisure and Enterprise, University of Wolverhampton Business School, Nursery Street, City Campus North, Wolverhampton, WV1 1AD, Email: n.stylos@wlv.ac.uk, Phone: +44 1902323741

${ }^{3}$ Assistant Professor, Department of Tourism Management, National Quemoy University, 1University RD., Jinning Township, Kinmen ,Taiwan, Email: yesso5@yahoo.com.tw, Phone: +886 935989605

Department of Tourism Management, National Quemoy University, 1University RD., Jinning Township, Kinmen, Taiwan, Email: e_y2177@yahoo.com.tw, Phone: +886 939502973

* Corresponding author
}

\section{Abstract}

The purpose of this study is to examine tourists' pre and post visit behaviours in Kinmen and the change of their perceived destination image about the place. Questionnaire interview was used to survey international tourists to Kinmen, Taiwan. The relevant survey was based on a selfadministered questionnaire that finally generated 563 responses out of initially 610 questionnaires that were distributed. Thus, the return rate was $94 \%$. The results indicate that pre-visit behaviour (comprised of motives, information search, and destination image) can influence post-visit behavioural intention directly and through decision making. Decision making also possess direct impact on post-visit behavioural intention, but has no mediating effect. The study has also indicated that certain socio-demographic variables possess significant influence on tourists' pre-visit behaviours. Firstly, young and non-married respondents with less monthly salary are more likely to visit Kinmen for learning motives. Secondly, education level is the strongest predictor for tourists' information search behaviours. Finally, socio-demographic variables possess little impact on destination image.

(C) 2015 International University College. All rights reserved

Keywords: destination image; decision making; information search; motives

Citation: Chang, L., Stylos, N., Yeh, S. and Tung, Y. (2015). How do Motivation, Pre-Visit Information Search and Destination Image affect Post-Visit Behavioural Intention? The case of an island destination. European Journal of Tourism Research 9, pp. 8-23

Introduction

Understanding the factors that serve as antecedents of post-visit behavioural intention of choosing a travel destination can be very 
beneficial both for tourism destinations marketing and management (Lam \& Hsu, 2006). It is true that decision making process for visiting a tourism destination and more specific the analysis of revealing the factors influencing (re)visit intentions are quite challenging (Vassiliadis et al., 2013; Chi \& Qu, 2008). In this endeavour of capturing most of tourists' behavioural aspects many models have been proposed and applied based on consumer behaviour theories and research frameworks (Lin, 2013; Assaker et al., 2011; Han \& Kim, 2010; Hung \& Petrick, 2012; Li et al., 2010; Kuo et al., 2011; Bigne et al., 2009; Lee et al., 2007; Hutchinson et al., 2007; Sirakaya \& Woodside, 2005; Um et al., 2006; George \& George, 2004; Anton et al., 2007; Castro et al., 2007; Bagozzi, 1992). Some examples of these models are the ones associated with the Theory of Reasoned Action, the Theory of Planned Behaviour, and the Motivation-Opportunity-Ability framework (Fishbein \& Ajzen, 1975; Ajzen, 1991; MacInnis \& Jaworski, 1989).

The survey of 2010 domestic travelling conducted by Taiwan's Tourism Bureau has indicated that $93.9 \%$ of Taiwanese citizens commenced in tourism activities at an average rate of 6.08 times per year (tpy), increased by 1.23 tpy compared to the relevant 2009 figure. This number is equivalent to 1.2 hundred million tourists per year, which corresponds to a $26.5 \%$ growth compared to 2009. In 2010, $79 \%$ of domestic travelling was promoted by tourism related motives and $88 \%$ of them chose to plan their trip on their own. Approximately $63 \%$ of domestic tourists visit a destination in the vicinity of their residence. It is also evident in that report that most domestic tourists have visited Northern Taiwan, whereas peripheral islands such as Kinmen receive only $0.4 \%$ of total domestic tourists. This means that the tourism potential of Kinmen is yet to be developed. Therefore, it is important to understand how to communicate in a more effective way with that market and how domestic tourists view Kinmen as a tourism destination (Fotiadis et al., 2014). The purpose of this study is then to understand tourists' previsit information search and decision making behaviour in Kinmen. Furthermore, the study examines the pre and post-visit destination image of the tourists.

\section{Literature Review}

Socio-demographic variables and pre-visit behaviours

Hedlund, Marell, and Gärling(2012) assert that a strong relationship exists between sociodemographic variables and consumer behaviours. Other researchers (Berman \& Evans, 1995) supported that sociodemographics can influence individual's problem recognition phase of decision making and thereby shape their motivations(Carneiro \& Eusébio, 2012) for shaping certain product or service preference.

Another interesting aspect arises when people plan their trip; socio-demographics often play an important role in their preference of information source (Lo, Cheung, \& Law, 2004). The information search variables can affect what source people choose and how they conduct their search (Fodness \& Murray, 1999).

Moreover, the connection between tourists' socio-demographics and destination image was largely researched by Prayag (2012). It has been claimed that socio-demographic variables greatly determine people's perceptions (Baloglu \& McCleary, 1999).

\section{Pre-visit behaviours and decision making process}

It has been supported that motive is the internal push factor that actually initiates the desire of the individual to engage in tourism activity in order to satisfy various needs (Schiffman \& Leslie, 2000). This study adopts the measurement instrument developed by Beard and Ragheb (1983) that was further modified to accommodate the special destination characteristics of Kinmen. Tourists' motive dimension is comprised of physical, psychological, education and culture, social interaction, and self-development elements. These motives determine how individuals evaluate various destination choices and make their final decision. Dann (1981), Yuan and McDonald (1990), as well as Pearce and Lee (2005) supported that self-development, novelty, relationship and relaxation \& escape 
How do Motivation, Pre-Visit Information Search and Destination Image affect Post-Visit Behavioural Intention? The case of an island destination.

are the core travel motivational factors. Additionally, Dunn Ross and Iso-Ahola (1991) claimed that tourists' motivational factors mainly consist of self-determination, sense of competence, challenge, learning, exploration and relaxation. Therefore, it is derived that selfdevelopment, relaxation, learning, and exploration are widely accepted as core factors of motivation.

Information search is well known in the area of consumer behaviour (Stigler, 1961) and it basically supports that consumers will continue to allocating resources for search until the utility gained from the search exceeds the relevant cost (Money and Crotts, 2003). Fodness and Murray (1999) recognize the supportive and decisive role that information plays on decision making process. It is also considered as the second stage of consumer decision process at the EBM model (Engel, Miniard, \& Blackwell, 2001) and it has been referred to be of great interest when exploring tourists' consumer behaviour (Xiang and Gretzel, 2010; Goossens, 2000; Dimanche and Havitz, 1995). In the tourism industry there are four types of information search that have been suggested by various scholars (Kerstetter and Cho, 2004; Crotts, 1999; Fodness and Murray, 1998): passive search, active search, prior experience and word-of-mouth advice. Passive search refers to mass media advertising used by tourism suppliers to communicate with general public (Moorthy et al., 1997). Active search refers to communication channels that tourists who are interested can access the information when they need to, such as Internet, blog, travel magazine, etc. (Kim et al., 2007). Tourists may use their or other people's past experience as guidance for information search (Lehto et al., 2006).Additionally, word-of-mouth in its traditional form, as well as in the modern electronic form through internet and particularly via social media has been referred to be an important source for information search (Gursoy and McCleary, 2004; Litvin et al., 2008). In our case, given the fact that the field research study took place in Kinmen, an island that receives small portion of total domestic tourism of Taiwan, there are many uncertainties regarding destination choice, transportation methods, and other considerations compared to other tourism destinations of Taiwan. It is reasonable to ascertain that tourists turn over certain amount of their attention to pre-visit information search in order to minimize the risks of unexpected trouble during their travel (Jang, 2005). The current study has adopted the model proposed by Fodness and Murray (1999) and has categorized information search into search source limit, search time limit, and search routine.

Destination image is another construct considered as a key component in determining destination choice (Baloglu \& Mangaloglu, 2001; Kamenidou et al., 2009; Pike, 2002). It is regarded as the subjective mental interpretation of beliefs, feelings and actions towards a destination (Agapito et al., 2013; Lai and Li, 2012; Žabkar et al., 2010). Leisen (2001) asserted that destination image helps tourists in their evaluation and decision making process. Tourists' personal experiences and their relevant information search helps them to form their perceptions of destination image that not only attract people to visit a destination, but also contribute to their willingness for repeat visitation (Fakeye \& Crompton, 1991).

\section{The antecedents of post-visit behaviours}

Engel et al. (2001) proposed that postconsumption evaluation is the stage where customers decide whether they are satisfied or dissatisfied with the goods possessed or services received. The consistency between customer expectation and post-consumption evaluation yields positive satisfaction, but failure of the products to meet customers' expectations will result in dissatisfaction. In general, customers incorporate the consumption experiences and satisfaction in their future decision making. Furthermore, customers tend to reciprocate the satisfaction by certain loyalty behaviours, such as repeat purchasing as well as advocating the products within their social environment.

Satisfaction is often being used as an indicator for evaluating tourists' experiences and measuring the quality of tourism product. Baker and Crompton (2000) point out that satisfaction is formed by tourists' personal interaction with the attributes of a destination. The pre-visit information search through advertising, 
brochures, and word-of-mouth recommendations helped in forming an expectation which is subsequently evaluated against the actual experiences towards assessing satisfaction (Akama \& Kieti, 2003). This study also adopts the views of scholars with respect to satisfaction, as an aspect of post-visit behaviour that is measured by the gaps between expectation and actual experiences.

Engel et al. (2001) have supported that behavioural intention is an individual's subjective judgment for future actions comprised of cognition, affection and intention.
Behavioural intention gradually consolidates to attitude which affects how one behaved. In marketing sense, the degree of satisfaction is a key contributor for repeat purchase and other loyalty behaviours.

On the basis of the variable relationships constructed in the research framework and the previous literature that was reviewed, the following hypotheses are offered:

\section{Sampling Methods and Survey}

The field research location is the island of Kinmen at the West of Taiwan. The

$H_{1}$

$H_{1-1}$ : Tourists' socio-demographics affect their motivation.

$H_{1-2}$ : Tourists' socio-demographics affect their information search behaviours.

$H_{1-3}$ : Tourists' socio-demographics affect their destination image.

$H_{2}$

$H_{2-1}$ : Tourists' motives affect their decision making.

$H_{2-2}$ : Tourists' information search affects their decision making.

$H_{2-3}$ : Tourists' destination image affects their decision making.

$H_{3}$

$H_{3-1}$ : Tourists' motives affect their post-visit behavioural intention.

$H_{3-2}$ : Tourists' information search affects their post-visit behavioural intention.

$H_{3-3}$ : Tourists' destination image affects their post-visit behavioural intention.

$\boldsymbol{H}_{4} \quad$ Tourists' decision making affects their post-visit behavioural intention.

$\mathrm{H}_{5}$

$H_{5-1}$ : Tourists' decision making is a mediator between their motives and post-visit behavioural intention.

$H_{5-2}$ : Tourists' decision making is a mediator between their information search and post-visit behavioural intention.

$H_{5-3}$ : Tourists' decision making is a mediator between their destination image and post-visit behavioural intention.

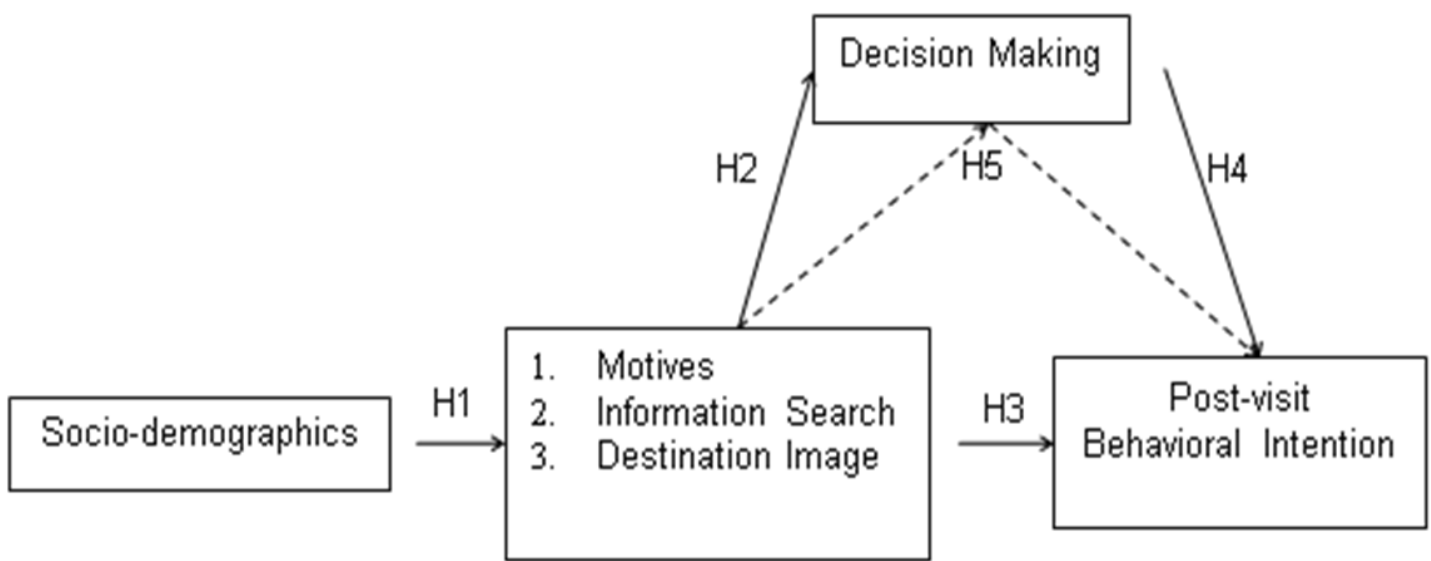

Figure 1. The Research Framework 
The case of an island destination.

researchers have travelled as individual tourists and interviewed other travellers during their trips. This procedure took place on ferries connecting mainland Taiwan with Kinmen island in both directions. Two 3-member-teams comprised of field researchers were asking every third passenger entering first class and economy class lounges of the ships to fill out the questionnaire. Given that decision making is a vital part of the research theme, the researchers have targeted travellers of 15 years of age and older that can actually make a decision for themselves concerning their vacations destination. The field research took place in two stages. The first stage was commenced in February 2012. The second survey was carried out between March and April 2012. Then, 596 questionnaires were finally gathered out of 610 tourists that were approached in total, resulting to a $97.7 \%$ return rate. After collecting the questionnaires, it was detected that some of them were almost totally incomplete due to lack of time or late refusal to complete the questionnaire on behalf of the respondents. Thus, a total of 563 valid questionnaires have been confirmed to be usable.

\section{Questionnaire design}

The questionnaire has been designed based on loans from literature review and is comprised of six parts: (1) decision making, (2) motivation, (3) information search, (4) destination image, (5) post-visit behavioural intention, and (6) socio-demographic information. The first and last sections of the questionnaire are comprised of ordinal, nominal, and open-ended questions. The main section related to the model's variables is comprised solely of 5- point Likert scale type questions.

\section{Data Analysis}

\section{Sample Characteristics}

The survey resulted to a collection of 563 valid responses, where 305 from female (54.17\%) and 258 from male (45.83\%) interviewees. Moreover, the sample is comprised of 266 $(47.25 \%)$ non-married respondents and 297 $(52.75 \%)$ married ones. The majority of respondents are between the ages of 20 to 59 years old, counting approximately for $70 \%$ of the sample. Five of the respondents $(0.89 \%)$ are under 19 years old and 7 of them (1.24\%) over 70 years old. There are 141 respondents $(25.04 \%)$ between the age of 20 and 29, 153 respondents (27.18\%) between 30 and 39 years old, 104 respondents (18.47\%) between 40 and 49 years old, and 120 respondents $(21.31 \%)$ between the age of 50 and 59 .

\section{Testing Hypothesis $\mathrm{H}_{1}$}

Hypothesis $H_{1}$ is to investigate the impact of socio-demographic variables on various previsit behaviours. Hypotheses 1-1, 1-2, and 1-3 were tested using an independent sample t-test and ANOVA, as presented on Tables 1,2 and 3.

As mentioned before, the construct of motives has been analysed into four sub-dimensions namely self-development, relaxation, learning, and exploration. Data analysis indicates that female respondents tend to possess a slightly higher level of motivation than males do with respect to the first three dimensions of motives (Table 1). However, only one case of mean difference is statistically significant where female respondents are more interested in relaxation motive $\left(t=-2.218^{*}\right)$. In terms of marital status, non-married respondents are more likely to be motivated by learning dimension of motivation than singles $\left(t=3.318^{*}\right)$. Respondents' monthly income also seems to exert a significant influence on only one category of motives, namely learning. In detail, the post-hoc (Scheffe) test has shown that respondents with a monthly income of NT\$ 65,000 or less are more likely to be motivated by their learning needs in comparison to respondents that earn NT\$95,001 or more per month. Age also affects significantly tourists' learning motive. In particular, respondents that are younger than 29 years old are more likely to be motivated by their learning motive than respondents between 40 and 49 years of age. Moreover, it is revealed that tourists' level of education does not significantly influence the four sub-dimensions of motives. As a whole, data analysis has shown that $H_{1-1}$ is partially supported by the empirical data. 
Table 1. Socio-demographic Variables and Motives

\begin{tabular}{|c|c|c|c|c|}
\hline Motives & $\begin{array}{c}\text { Self } \\
\text { development }\end{array}$ & Relaxation & Learning & Exploration \\
\hline Average & 3.455 & 4.134 & 4.044 & 4.108 \\
\hline \multicolumn{5}{|l|}{ Gender } \\
\hline (a)Male (258) & 3.443 & 4.076 & 4.017 & 4.112 \\
\hline (b)Female (305) & 3.465 & 4.184 & 4.066 & 4.104 \\
\hline t-value & -0.388 & $-2.218^{*}$ & -0.836 & 0.168 \\
\hline Mean difference & - & $b>a$ & - & - \\
\hline \multicolumn{5}{|l|}{ Marital Status } \\
\hline (a)Single (266) & 3.456 & 4.151 & 4.143 & 4.155 \\
\hline (b)Married (297) & 3.455 & 4.119 & 3.955 & 4.066 \\
\hline t-value & 0.013 & 0.653 & $3.318^{*}$ & 1.714 \\
\hline Mean difference & - & - & $a>b$ & - \\
\hline \multicolumn{5}{|l|}{ Monthly Income in NT\$ } \\
\hline (a) 35,000 or less (260) & 3.470 & 4.141 & 4.119 & 4.106 \\
\hline (b) $35,001 \sim 50,000(132)$ & 3.512 & 4.189 & 4.057 & 4.178 \\
\hline (c) $50,001 \sim 65,000(75)$ & 3.433 & 4.179 & 4.100 & 4.108 \\
\hline (d) $65,001 \sim 80,000(39)$ & 3.361 & 3.959 & 3.833 & 4.026 \\
\hline (e) $80,001 \sim 95,000(27)$ & 3.401 & 4.170 & 3.889 & 4.130 \\
\hline (f) 95,001 or more (30) & 3.302 & 3.910 & 3.600 & 3.900 \\
\hline F-value & 0.733 & 1.976 & $4.463^{*}$ & 1.175 \\
\hline Scheffe & - & - & $a, b, c>f$ & - \\
\hline \multicolumn{5}{|l|}{ Age } \\
\hline (a) 29 or less (146) & 3.447 & 4.177 & 4.188 & 4.171 \\
\hline (b) $30-39(153)$ & 3.441 & 4.161 & 4.042 & 4.098 \\
\hline (c) $40-49(104)$ & 3.436 & 4.134 & 3.933 & 3.981 \\
\hline (d) 50 or more (160) & 3.490 & 4.070 & 3.984 & 4.142 \\
\hline F-value & 0.204 & 1.024 & $3.577^{*}$ & 2.177 \\
\hline Scheffe & - & - & $a>c$ & - \\
\hline
\end{tabular}

Note: * $p<0.05 ;$ () no. of respondents; 1 USD $\approx 30$ NT\$

Testing of $H_{1-2}$ has provided some interesting results that are summarized on Table 2. As aforementioned, four types of information search that have been reported including passive source, active source, past experience, and word of mouth. The results indicate that gender only exert a significant influence on word-of-mouth. Female respondents are more likely to use word-of-mouth as a source of information $\left(\mathrm{t}=-2.810^{*}\right)$. In terms of marital status, non-married tourists are more likely to use active source to search for information $\left(\mathrm{t}=2.099^{*}\right)$. Monthly income and age exert no statistically significant influence on information search behaviours. On the other hand, the level of tourists' education significantly affects active information sourcing, past experience and word-of-mouth communication. In particular, respondents with higher level of education is more likely to relied on active source for information, while lower education level respondents tend to use their past experience and word of mouth. Therefore, hierarchical analysis of data supports $H_{1-2}$ only partially. 
How do Motivation, Pre-Visit Information Search and Destination Image affect Post-Visit Behavioural Intention? The case of an island destination.

Table 2. Socio-demographic Variables and Information Search

\begin{tabular}{lcccc}
\hline \multicolumn{1}{c}{ Information Search } & $\begin{array}{c}\text { Passive } \\
\text { source }\end{array}$ & Active source & $\begin{array}{c}\text { Past } \\
\text { experience }\end{array}$ & $\begin{array}{c}\text { Word of } \\
\text { mouth }\end{array}$ \\
\hline Average & 3.575 & 3.864 & 3.116 & 3.942 \\
Gender & & & & \\
(a)Male (258) & 3.555 & 3.854 & 3.175 & 3.860 \\
(b)Female (305) & 3.591 & 3.873 & 3.066 & 4.012 \\
t-value & -0.617 & -0.335 & 1.350 & $-2.810^{*}$ \\
Mean difference & - & - & - & b>a \\
Marital Status & & & & \\
(a) Single (266) & 3.543 & 3.924 & 3.083 & 3.932 \\
(b)Married (297) & 3.603 & 3.810 & 3.145 & 3.951 \\
t-value & -1.026 & $2.099^{*}$ & -0.772 & -0.352 \\
Mean difference & - & $a>b$ & - & - \\
Education Level & & & & \\
(a) High school or less (134) & 3.629 & 3.742 & 3.284 & 4.078 \\
(b) Junior college (118) & 3.612 & 3.809 & 3.123 & 3.898 \\
(c) University (311) & 3.537 & 3.938 & 3.040 & 3.900 \\
F-value & 1.033 & $4.810^{*}$ & $3.039^{*}$ & 4.081 \\
Scheffe & - & $\mathrm{c}>\mathrm{a}$ & $\mathrm{a}>\mathrm{c}$ & $\mathrm{a}>\mathrm{c}$ \\
\hline Note* ${ }^{*}$ p<0.05:() no. of respondents: 1 USD 30NT\$ & & &
\end{tabular}

Table 3. Socio-demographic Variables and Destination Image

\begin{tabular}{|c|c|c|c|}
\hline Destination Image & $\begin{array}{l}\text { Accessibility } \\
\text { and comfort }\end{array}$ & Entertainment & $\begin{array}{c}\text { History and } \\
\text { culture }\end{array}$ \\
\hline Average & 4.035 & 3.654 & 4.183 \\
\hline \multicolumn{4}{|l|}{ Gender } \\
\hline (a)Male (258) & 4.058 & 4.035 & 3.696 \\
\hline (b)Female (305) & 4.035 & 3.603 & 4.183 \\
\hline t-value & 0.013 & -1.408 & -0.015 \\
\hline \multicolumn{4}{|l|}{ Marital Status } \\
\hline (a)Single (266) & 4.086 & 3.702 & 4.226 \\
\hline (b)Married (297) & 3.989 & 3.610 & 4.145 \\
\hline t-value & $1.966^{*}$ & 1.387 & 1.654 \\
\hline Mean difference & $a>b$ & - & - \\
\hline
\end{tabular}

The third part of hypothesis $H_{1}$ is devoted to examining the influence of socio-demographic variables on tourists' perceived destination image. As indicated on Table 3, only marital status significantly affects tourists' accessibility and comfort aspect of destination image. Singles are more likely to express a high evaluation on the destination's accessibility and comfort $\left(\mathrm{t}=1.966^{*}\right)$ than tourists that are married. Therefore, $H_{1-3}$ is partially supported. 
The Impacts of Motives

The impacts of motives on decision making $\left(H_{2}\right.$ 1), post-visit behavioural intention $\left(H_{3-1}\right)$, and the mediating effect $\left(H_{5-1}\right)$ were tested employing hierarchical regression analysis. The first group of relationships, concerning submodels 1-1, 1-2 and 1-3 examine possible influences of tourists' motives on their decision making. Data analysis $\left(\mathrm{R}^{2}=0.053, \mathrm{~F}=7.580\right.$, $\mathrm{p}<0.001)$ indicates that the causal relationship between motives and decision making is statistically significant. In detail, selfdevelopment and relaxation motive subdimensions tend to have a positive impact on tourists' decision making including their repeat visitation, days spent at destination, and expenditure. On the other hand, motives have no significant impact on the days spent by tourists in Kinmen island. Therefore, $\mathrm{H}_{2-1}$ is partially supported.

Statistical analysis related to model 2 is presented on Table 4 and it indicates that motives significantly affect tourists' post-visit or revisit behavioural intention $\left(R^{2}=0.201\right.$, $\mathrm{F}=34.262, \quad \mathrm{p}<0.001)$. Therefore, $H_{3-1}$ is confirmed.

Model 3 related statistics included on Table 4 examine hypothesis $H_{5-1}$, assuming that tourists' decision making is a mediator between their motives and post-visit behavioural intention. Summary statistics of model 3 $\left(R^{2}=0.214, F=21.022, p<0.001\right)$ indicates that both motives and related decision making exert a strong influence on tourists' post-visit behavioural intention as it has been determined previously. A comparison of the indices for models 2 and 3 reveals that $\beta$ values of motives have not decreased and at the same time the $R^{2}$ value has increased from 0.201 to 0.214 . Therefore, a mediating effect cannot be statistically supported, meaning that $H_{5-1}$ is rejected.

Table 4. Hierarchical Regression to test the possible Impacts of Motives

Dependent Variable

\begin{tabular}{|c|c|c|c|c|c|c|}
\hline \multirow{2}{*}{\multicolumn{2}{|c|}{ Independent Variables }} & \multirow{3}{*}{$\begin{array}{l}\text { No. visit } \\
\text { model 1-1 } \\
\text { B }\end{array}$} & \multirow{3}{*}{$\begin{array}{c}\text { Days visit } \\
\text { model 1-2 } \\
\beta\end{array}$} & \multirow{3}{*}{$\begin{array}{l}\text { Expenditure } \\
\text { Model 1- } 3 \\
\beta\end{array}$} & \multirow{3}{*}{$\begin{array}{c}\begin{array}{c}\text { Behavioural } \\
\text { intention } \\
\text { model } 2\end{array} \\
\beta\end{array}$} & \multirow{3}{*}{$\begin{array}{c}\begin{array}{c}\text { Behavioural } \\
\text { intention } \\
\text { model } 3\end{array} \\
\beta\end{array}$} \\
\hline & & & & & & \\
\hline & & & & & & \\
\hline \multirow{5}{*}{ Motives } & (Constant) & & & & & \\
\hline & Self & $0.159^{*}$ & 0.073 & $0.138^{* *}$ & $0.101^{*}$ & $0.102^{*}$ \\
\hline & Relaxation & $0.135^{\star}$ & 0.055 & 0.076 & $0.138^{*}$ & $0.135^{*}$ \\
\hline & Learning & $-0.146^{*}$ & 0.066 & -0.106 & $0.185^{\star}$ & $0.180^{*}$ \\
\hline & Exploration & $-0.188^{*}$ & -0.038 & -0.098 & $0.146^{*}$ & $0.150^{*}$ \\
\hline \multirow{3}{*}{$\begin{array}{l}\text { Decision } \\
\text { Making }\end{array}$} & No. visit & & & & & 0.067 \\
\hline & Days visit & & & & & 0.042 \\
\hline & Expenditure & & & & & $-0.107^{*}$ \\
\hline \multirow{5}{*}{$\begin{array}{l}\text { Summary } \\
\text { of model }\end{array}$} & $\mathrm{R}^{2}$ & 0.053 & 0.020 & 0.023 & 0.201 & 0.214 \\
\hline & Adjusted $\mathrm{R}^{2}$ & 0.046 & 0.012 & 0.016 & 0.195 & 0.203 \\
\hline & $\mathrm{F}$ & $7.580^{\star}$ & $2.720^{*}$ & $3.271^{*}$ & $34.262^{*}$ & $21.022^{*}$ \\
\hline & $\Delta \mathrm{R}^{2}$ & - & - & - & 0.201 & 0.013 \\
\hline & $\Delta \mathrm{F}$ & - & - & - & $34.262^{*}$ & $2.892^{*}$ \\
\hline
\end{tabular}


How do Motivation, Pre-Visit Information Search and Destination Image affect Post-Visit Behavioural Intention?

The case of an island destination.

Table 5. Hierarchical Regression to test the possible Impacts of Information Search

Dependent Variable

\begin{tabular}{|c|c|c|c|c|c|c|}
\hline \multirow{2}{*}{\multicolumn{2}{|c|}{ Independent Variables }} & \multirow{3}{*}{$\begin{array}{c}\text { No. visit } \\
\text { model 1-1 } \\
\beta\end{array}$} & \multirow{3}{*}{$\begin{array}{c}\text { Day visit } \\
\text { model 1-2 } \\
\beta\end{array}$} & \multirow{3}{*}{$\begin{array}{c}\text { Expenditure } \\
\text { Model 1-3 } \\
\beta\end{array}$} & \multirow{3}{*}{$\begin{array}{c}\begin{array}{c}\text { Behavioural } \\
\text { intention } \\
\text { model } 2\end{array} \\
\beta\end{array}$} & \multirow{3}{*}{$\begin{array}{c}\text { Behavioural } \\
\text { intention } \\
\text { model } 3\end{array}$} \\
\hline & & & & & & \\
\hline & & & & & & \\
\hline \multirow{5}{*}{$\begin{array}{l}\text { Information } \\
\text { Search }\end{array}$} & (Constant) & & & & & \\
\hline & Passive source & $0.137^{*}$ & 0.031 & 0.110 & 0.068 & 0.072 \\
\hline & Active source & -0.106 & $0.111^{*}$ & $-0.109^{*}$ & $0.280^{*}$ & $0.264^{*}$ \\
\hline & Past experience & 0.040 & 0.004 & $0.147^{*}$ & -0.066 & -0.053 \\
\hline & Word of mouth & 0.024 & -0.069 & -0.001 & $0.245^{*}$ & $0.249^{*}$ \\
\hline \multirow{3}{*}{$\begin{array}{l}\text { Decision } \\
\text { Making }\end{array}$} & No. visit & & & & & 0.036 \\
\hline & Day visit & & & & & 0.077 \\
\hline & Expenditure & & & & & $-0.101^{*}$ \\
\hline \multirow{5}{*}{$\begin{array}{l}\text { Summary } \\
\text { of model }\end{array}$} & $\mathrm{R}^{2}$ & 0.019 & 0.015 & 0.038 & 0.227 & 0.239 \\
\hline & Adjusted $\mathrm{R}^{2}$ & 0.011 & 0.007 & 0.031 & 0.222 & 0.229 \\
\hline & $\mathrm{F}$ & $2.578^{\star}$ & 2.020 & $5.416^{\star}$ & $40.194^{*}$ & $24.402^{*}$ \\
\hline & $\Delta R^{2}$ & - & - & - & 0.227 & 0.012 \\
\hline & $\Delta \mathrm{F}$ & - & - & - & $40.194^{*}$ & $2.813^{*}$ \\
\hline
\end{tabular}

The impacts of information search

The impacts of information search on decision making $\left(H_{2-2}\right)$, post-visit behavioural intention $\left(H_{3-2}\right)$, and the mediating effect $\left(H_{5-2}\right)$ were also tested using hierarchical regression analysis. As explained earlier, four types of information search behaviours were used as independent variables and decision making behaviours as dependent variables. As indicated on Table 5, the summary of statistics for model 1-1 $\left(R^{2}=0.019, F=2.578, p<0.05\right)$ supports that it is statistically significant suggesting that information search behaviours affect tourists' repeat visitation. As whole, results present that $H_{2-2}$ is only partially supported.

Hypothesis $H_{3-2}$ has been included in this study in order to examine the causal relationship between information search and post-visit behavioural intention. As indicated in model 2 of Table 5, the causal relationship between the two variables is significant $\left(R^{2}=0.227\right.$,
$\mathrm{F}=40.194, \mathrm{p}<0.001)$. Thus, $H_{3-2}$ is confirmed by data analysis.

Finally, the mediating effect of decision making on information search and post-visit behavioural intention is examined by using hierarchical regression. It is derived that similarly to model 2 related statistical analysis, the summary of statistics for model 3 is also significant $\left(R^{2}=0.239, \quad F=24.402, \quad p<0.001\right)$. What is more, a comparison of the $\beta$ values for models 2 and 3 does not show a statistically significant decline and at the same time $R^{2}$ values for these two models increase from 0.227 to 0.239 . Consequently, the mediating effect is not confirmed and therefore $H_{5-2}$ is not supported.

\section{The impacts of destination image}

The investigations of the impacts exerted from destination image on decision making $\left(\mathrm{H}_{2-3}\right)$, post-visit behavioural intention $\left(H_{3-3}\right)$, as well as 
image's involvement in the mediating effect with decision making $\left(H_{5-3}\right)$, are considered to be of crucial importance. Destination image attributes have been grouped into three dimensions, namely accessibility \& comfort, entertainment, and history \& culture. Statistical analysis for models 1-1, 1-2, and 1-3 (Table 6) is related to the examination of $H_{2-3}$. The summary of statistics for models $1-1$ and 1-2 $\left(\mathrm{R}^{2}=0.014 ; \quad \mathrm{F}=2.650 ; \quad \mathrm{p}<0.05\right) \quad$ indicates significant causal relations between destination image and decision making. Further examination of the $\beta$ values reveals that "Do It Yourself" (DIY) tourists did not visit Kinmen for its entertainment attributes.

Then, model 2 of table 6 has been constructed to test $H_{3-3}$. The relevant model summary $\left(R^{2}=0.239, \quad F=57.933, \quad p<0.001\right)$ indicates a strong relationship between destination image and post-visit behavioural intention.

Hierarchical regression has been also employed to reveal any mediating effects of decision between destination image and postvisit behavioural intention. Model 3 statistics summary depicted on Table 6 indicates a significant causal relationship between destination image and post-visit behavioural intention $\left(R^{2}=0.248, \quad F=30.229, \quad p<0.001\right)$. However, $\beta$ values of two models are quite similar and the $R^{2}$ values increase from 0.239 to 0.248 , suggesting that the mediating effect of decision making is not supported. Based on this result and the previous evidence, the study can conclude that decision making does not serve as a mediator between pre and post visit behaviours.

A last interesting relationship concerns decision making and post-behavioural intention. Analysis for model 3 investigating antecedents of behavioural intention (Tables 4, 5 and 6) provides us with the following conclusion: in all three alternatives of post-behavioural intention modelling there are strong direct causal and statistically significant relationships between decision making and post-behavioural

Table 6. Hierarchical Regression to test the possible Impacts of Destination Image

Dependent Variable

\begin{tabular}{|c|c|c|c|c|c|c|}
\hline \multirow{2}{*}{\multicolumn{2}{|c|}{ Independent Variables }} & \multirow{3}{*}{$\begin{array}{l}\text { No. visit } \\
\frac{\text { Model 1-1 }}{\beta}\end{array}$} & \multirow{3}{*}{$\begin{array}{c}\text { Day visit } \\
\text { model 1-2 } \\
\beta\end{array}$} & \multirow{3}{*}{$\begin{array}{c}\text { Expenditure } \\
\text { Model 1- } 3 \\
\beta\end{array}$} & \multirow{3}{*}{$\begin{array}{c}\begin{array}{c}\text { Behavioural } \\
\text { intention } \\
\text { model } 2\end{array} \\
\beta\end{array}$} & \multirow{3}{*}{$\begin{array}{c}\begin{array}{c}\text { Behavioural } \\
\text { intention } \\
\text { model } 3\end{array} \\
\beta\end{array}$} \\
\hline & & & & & & \\
\hline & & & & & & \\
\hline \multirow{4}{*}{$\begin{array}{l}\text { Destination } \\
\text { Image }\end{array}$} & (Constant) & & & & & \\
\hline & $\begin{array}{l}\text { Accessibility } \\
\text { and comfort }\end{array}$ & 0.096 & $0.183^{*}$ & -0.017 & $0.391^{*}$ & $0.378^{*}$ \\
\hline & Entertainment & $-0.164^{*}$ & -0.085 & -0.018 & -0.067 & -0.058 \\
\hline & $\begin{array}{l}\text { History } \\
\text { and culture }\end{array}$ & 0.047 & 0.012 & 0.023 & $0.199^{*}$ & $0.199^{*}$ \\
\hline \multirow{3}{*}{$\begin{array}{l}\text { Decision } \\
\text { Making }\end{array}$} & No. visit & & & & & 0.043 \\
\hline & Day visit & & & & & 0.043 \\
\hline & Expenditure & & & & & $-0.095^{\star}$ \\
\hline \multirow{5}{*}{$\begin{array}{l}\text { Summary } \\
\text { of model }\end{array}$} & $\mathrm{R}^{2}$ & 0.014 & 0.020 & 0.001 & 0.239 & 0.248 \\
\hline & Adjusted $\mathrm{R}^{2}$ & 0.009 & 0.014 & -0.005 & 0.235 & 0.239 \\
\hline & $F$ & $2.650^{*}$ & $3.705^{\star}$ & 0.147 & $57.933^{*}$ & $30.229^{*}$ \\
\hline & $\Delta \mathrm{R}^{2}$ & - & - & - & 0.239 & 0.009 \\
\hline & $\Delta \mathrm{F}$ & - & - & - & $57.933^{*}$ & 2.160 \\
\hline
\end{tabular}


How do Motivation, Pre-Visit Information Search and Destination Image affect Post-Visit Behavioural Intention?

The case of an island destination.

intention. Thus, $\mathrm{H}_{4}$ is confirmed by data analysis.

A summary of all results is presented on Table 7 .

\section{Conclusions and Suggestions \\ Concluding remarks}

The results indicate that pre-visit factors (motives, information search, and destination image) exert some significant influence on tourists' decision making and post-visit behavioural intention, also confirmed by Moutinho (1987), Cai et al. (2004), Li et al. (2010) and Murphy et al. (2007).

Some of the socio-demographic variables significantly impact pre-visit behavioural factors, thus confirming other studies of Yuan et al. (2008), Su and Wall (2009), Mules et al. (2007) and Andriotis \& Agiomirgianakis (2010). However, there is only partial support for the hypotheses assuming significant influences of socio-demographics on motivation, information search and destination image. For example, $H_{1-1}$ indicates that young and non-married respondents with lower monthly salary are more likely than any others to visit Kinmen driven from their learning motives. Similar conclusions have been reported by Stronza (2007), Wang (2004) and Loker-Murphy and Pearce (1995).

Then, pre-visit behavioural factors have been confirmed to exert some impact on tourists' decision making. Hypothesis $\mathrm{H}_{2-1}$ indicates that motives can significantly influence tourists' willingness for repeat visitation. Lau and McKercher (2004) and Fakeye and Crompton (1991) have also come to this conclusion. Then, $H_{2-2}$ indicates that some information search factors impact on tourists' expenditure. However, investigation of destination image impact on decision making by $\mathrm{H}_{2-3}$ provides partial support to the argument and it does not make clear if Kinmen's destination image plays a significant role in tourists' decision making, which is similar to the claims of Chalip et al. (2003). This should probably be due to the fact that till now there is not a specific strategy for constructing a favourable destination image for Kinmen in Taiwanese people's minds.

Third, it appears that pre-visit behaviour can directly influence tourists' post-visit behavioural intention, similarly to research conclusions of Chen and Tsai (2007). Hypothesis $H_{3-1}$ has been supported by data analysis indicating a strong causal relationship between the two stages of behaviour. Moreover, $\mathrm{H}_{3-2}$ indicates that active search and word-of-mouth are those information search types that exert a significant positive impact on post-visit behavioural intention. Romanazzi et al. (2011) and Tham et al. (2013) have also come to this conclusion concerning electronic and social media wordof-mouth. Hypothesis $\mathrm{H}_{3-3}$ indicates that tourists are not attracted by Kinmen's entertainment attribute.

Hypothesis $H_{4}$ is fully supported suggesting a

Table 7. Summary of Results

\begin{tabular}{|c|c|c|}
\hline Hypothesis & Content & Result \\
\hline$H_{1-1}$ & Socio-demographics $\rightarrow$ motivation & Partially supported \\
\hline$H_{1-2}$ & Socio-demographics $\rightarrow$ information search factors & Partially supported \\
\hline$H_{1-3}$ & Socio-demographics $\rightarrow$ their destination image & Partially supported \\
\hline$H_{2-1}$ & Motives $\rightarrow$ decision making & Partially supported \\
\hline$H_{2-2}$ & Information search $\rightarrow$ decision making & Partially supported \\
\hline$H_{2-3}$ & Destination image $\rightarrow$ decision making & Partially supported \\
\hline$H_{3-1}$ & Motives $\rightarrow$ post-visit behavioural intention & Confirmed \\
\hline$H_{3-2}$ & Information search $\rightarrow$ Post-visit behavioural intention & Partially supported \\
\hline$H_{3-3}$ & Destination image $\rightarrow$ post-visit behavioural intention & Partially supported \\
\hline$H_{4}$ & Decision making $\rightarrow$ post-visit behavioural intention & Confirmed \\
\hline$H_{5-1}$ & $\begin{array}{l}\text { Decision making is a mediator between their motive and post-visit } \\
\text { behavioural intention }\end{array}$ & Not supported \\
\hline$H_{5-2}$ & $\begin{array}{l}\text { Decision making is a mediator between their information search } \\
\text { and post-visit behavioural intention }\end{array}$ & Not supported \\
\hline$H_{5-3}$ & $\begin{array}{l}\text { Decision making is a mediator between their destination image } \\
\text { and post-visit behavioural intention }\end{array}$ & Not supported \\
\hline
\end{tabular}


causal relationship between decision making and post-visit behavioural intention. Hypothesis $\mathrm{H}_{5}$ is not supported indicating that decision making is not a statistically significant mediator between pre- and post-visit behavioural constructs. Sparks (2007) has similarly concluded that attitude does not mediate between pre-visit expectations and post-visit intentions.

From these results, the study can conclude that decision making can help to influence post-visit behavioural intention, but is not able to amplify the impacts of pre-visit behaviours on post-visit behavioural intention.

\section{Managerial Implications}

The results clearly indicate that tourists are more interested in the history and cultural aspects of Kinmen. Therefore, there are two possible approaches to improve Kinmen's attractiveness. First, destination managers planning Kinmen tourism product can base their efforts on island's historical and cultural values and possibly use them as a theme for their advertisement. These suggestions agree with similar results published by Stylos \& Andronikidis (2013), Vassiliadis et al. (2013), as well as Priporas et al. (2012).

In terms of information search, it is evident that respondents mostly rely on active search and word of mouth information types, confirming previously published research that specifically underlines the contribution of electronic communications in influencing tourists' decision making (Medhekar \& Newby, 2011; Sarma, 2007; Zins, 2007; Thapa et al., 2002). This potentially suggests that many tourists probably plan to visit Kinmen, largely associated with actively receiving information from people that previously visited Kinmen. Thus, it seems that Kinmen's island tourism product is currently at an early growth stage with a large future potential.

Finally, due to the fact that Kinmen is an island with insufficient connections of transportation means, accessibility is probably the most important concern for all potential Kinmen tourists. Frequent airline connections between Kinmen and Taiwan would obviously facilitate tourists revisiting again in the future.
Research limitations and suggestions for future research

The study has focused on DIY tourists. This is due to the fact that Kinmen is a very small island and receives only a small portion of Taiwan's domestic tourists. Therefore, marketing Kinmen as a mass tourism destination is still yet to be discussed. Therefore, it would be interesting if some future research studies could include this type of tourism.

Another useful aspect for future research would be investigating the tourists' expenditure while staying at the island of Kinmen in their specific types, such as entertainment, shopping, purchase of local products, as well as souvenirs to take away, apart from lodging, vehicle hires or other forms of transportation.

\section{References}

Agapito, D., Oom do Valle, P., \& da Costa Mendes, J. (2013). The CognitiveAffective-Conative Model of Destination Image: A Confirmatory Analysis. Journal of Travel \& Tourism Marketing, 30(5), 471-481.

Ajzen, I. (1991). The theory of planned behaviour. Organizational Behaviour and Human Decision Processes, 50(2) $179-211$.

Akama, J. S., \& Kieti, D. M. (2003). Measuring tourist satisfaction with Kenya's wildlife safari: a case study of Tsavo West National Park. Tourism Management, 24(1), 73-81.

Andriotis, K., \& Agiomirgianakis, G. (2010). Cruise visitors' experience in a Mediterranean port of call. International Journal of Tourism Research, 12(4), 390-404.

Antón, C., Camarero, C., \& Carrero, M. (2007). The mediating effect of satisfaction on consumers' switching intention. Psychology \& Marketing, 24(6), 511538.

Assaker, G., Vinzi, V. E., \& O'Connor, P. (2011). Examining the effect of novelty seeking, satisfaction, and destination image on tourists' return pattern: A two factor, non-linear latent growth model. Tourism Management, 32(4), 890-901. 
How do Motivation, Pre-Visit Information Search and Destination Image affect Post-Visit Behavioural Intention? The case of an island destination.

Bagozzi, R. P. (1992). The self-regulation of attitudes, intentions, and behaviour. Social Psychology Quarterly, 55(2), 178-204.

Baker, D. A., \& Crompton, J. L. (2000). Quality, satisfaction and behavioural intentions. Annals of Tourism Research, 27(3), 785- 804

Baloglu, S., \& Mangaloglu, M. (2001). Tourism destination images of Turkey, Egypt, Greece, and Italy as perceived by USbased tour operators and travel agents. Tourism Management, 22(1), 1-9.

Baloglu, S., \& McCleary, K. W. (1999). A model of destination image formation. Annals of Tourism Research, 26(4), 868-897.

Beard, J. G., \& Ragheb, M. G. (1983). Measuring leisure motivation. Journal of Leisure Research, 15(3), 219-228.

Berman, B., \& Evans, J. R. (1995). Retail Management: A Strategic Approach (8 ed.). New York: Macmillan Publishing Company.

Bigné Alcañiz, E., Sánchez García, I., \& Sanz Blas, S. (2009). The functionalpsychological continuum in the cognitive image of a destination: A confirmatory analysis. Tourism Management, 30(5), 715-723.

Cai, L. A., Feng, R., \& Breiter, D. (2004). Tourist purchase decision involvement and information preferences. Journal of Vacation Marketing, 10(2), 138-148.

Carneiro, M. J., \& Eusébio, C. (2012). Segmentation of the tourism market using the impact of tourism on quality of life. Tourism \& Management Studies, 7, 91-100.

Castro, C. B., Martín Armario, E., \& Martín Ruiz, D. (2007). The influence of market heterogeneity on the relationship between a destination's image and tourists' future behaviour. Tourism Management, 28(1), 175-187.

Chalip, L., Green, B. C., \& Hill, B. (2003). Effects of sport event media on destination image and intention to visit. Journal of Sport Management, 17(3), 214-234.

Chen, C. F., \& Tsai, D. (2007). How destination image and evaluative factors affect behavioural intentions?. Tourism management, 28(4), 1115-1122.
Chi, C. G. Q., \& Qu, H. (2008). Examining the structural relationships of destination image, tourist satisfaction and destination loyalty: An integrated approach. Tourism Management. 29(4), 624-636.

Crotts, J. (1999). Consumer decision making and prepurchase information search. In A. Pizam \& Y. Mansfeld (Eds.), Consumer Behaviour in Travel and Tourism, New York: Haworth Press New York, 149-168.

Dann, G. (1981). Tourist motivation an appraisal. Annals of Tourism Research, 8(2), 187-219.

Dimanche, F., \& Havitz, M. E. (1995). Consumer behaviour and tourism: Review and extension of four study areas. Journal of Travel \& Tourism Marketing, 3(3), 37-57.

Dunn Ross, E. L., \& Iso-Ahola, S. E. (1991). Sightseeing tourists' motivation and satisfaction. Annals of Tourism Research, 18(2), 226-237.

Engel, J. F., Miniard, P. W., \& Blackwell, R. D. (2001). Consumer Behaviour (9 ed.). New York: The Dryden Press.

Fakeye, P. C., \& Crompton, J. L. (1991). Image differences between prospective, firsttime, and repeat visitors to the Lower Rio Grande Valley. Journal of Travel Research, 30(2), 10-16.

Fishbein, M., \& Ajzen, I. (1975). Belief, attitude, intention, and behaviour: An introduction to theory and research. Boston: Addison - Wesley.

Fodness, D., \& Murray, B. (1998). A typology of tourist information search strategies. Journal of Travel Research, 37(2), 108119.

Fodness, D., \& Murray, B. (1999). A model of tourist information search behaviour. Journal of Travel Research, 37(3), 220230.

Fotiadis, A. K., Vassiliadis, C. A., \& Piper, L. A. (2014). Measuring dimensions of business effectiveness in Greek rural tourism areas. Journal of Hospitality Marketing \& Management, 23(1), 21 . 48.

George, B. P., \& George, B. P. (2004). Past Visits and the Intention to Revisit a 
Destination. The Journal of Tourism Studies, 15(2), 51-66.

Goossens, C. (2000). Tourism information and pleasure motivation. Annals of Tourism Research, 27(2), 301-321.

Gursoy, D., \& McCleary, K. W. (2004). An integrative model of tourists' information search behaviour. Annals of Tourism Research, 31(2), 353-373.

Han, H., \& Kim, Y. (2010). An investigation of green hotel customers' decision formation: Developing an extended model of the theory of planned behaviour. International Journal of Hospitality Management, 29(4), 659668.

Hedlund, T., Marell, A., \& Gärling, T. (2012). The mediating effect of value orientation on the relationship between socio-demographic factors and environmental concern in Swedish tourists' vacation choices. Journal of Ecotourism, 11(1), 16-33.

Hung, K., \& Petrick, J. F. (2012). Testing the effects of congruity, travel constraints, and self-efficacy on travel intentions: An alternative decision-making model. Tourism Management, 33(4), 855-867.

Hutchinson, J., Lai, F., \& Wang, Y. (2009). Understanding the relationships of quality, value, equity, satisfaction, and behavioural intentions among golf travelers. Tourism Management, 30(2), 298-308.

Jang, S. (2005). The past, present, and future research of online information search. Journal of Travel \& Tourism Marketing, 17(2-3), 41-47.

Kamenidou, I., Mamalis, S. and Priporas, C.V. (2009). Measuring destination image and consumer choice criteria. The case of Mykonos island. TOURISMOS: An International Multidisciplinary Journal of Tourism, 4(3), 67-79.

Kerstetter, D., \& Cho, M. H. (2004). Prior knowledge, credibility and information search. Annals of Tourism Research, 31(4), 961-985.

Kim, D. Y., Lehto, X. Y., \& Morrison, A. M. (2007). Gender differences in online travel information search: Implications for marketing communications on the internet. Tourism Management, 28(2), 423-433.

Kuo, C. T., Hung, Y. H., Hou, Y. H., \& Chang, F. H. (2011). Elucidating leisure constraints and experience, satisfaction and revisiting willingness among tourists to Dong Shi Fisherman's Wharf in Taiwan. African Journal of Business Management, 15(5), 6309-6317.

Lai, K., \& Li, Y. (2012). Core-periphery structure of destination image: Concept, evidence and implication. Annals of Tourism Research, 39(3), 1359-1379.

Lau, A. L., \& McKercher, B. (2004). Exploration versus acquisition: A comparison of first-time and repeat visitors. Journal of Travel Research, 42(3), 279-285.

Lee, S. Y., Petrick, J. F., \& Crompton, J. (2007). The roles of quality and intermediary constructs in determining festival attendees' behavioural intention. Journal of Travel Research, 45(4), 402-412.

Lehto, X. Y., Kim, D. Y., \& Morrison, A. M. (2006). The effect of prior destination experience on online information search behaviour. Tourism and Hospitality Research, 6(2), 160-178.

Leisen, B. (2001). Image segmentation: The case of a tourism destination. Journal of Services Marketing, 15(1), 49-66.

Li, M., Cai, L. A., Lehto, X. Y., \& Huang, J. (2010). A missing link in understanding revisit intention-The role of motivation and image. Journal of Travel \& Tourism Marketing, 27(4), 335-348.

Lin, C. H. (2013). Determinants of revisit intention to a hot springs destination: Evidence from Taiwan. Asia Pacific Journal of Tourism Research, 18(3), 183-204.

Litvin, S. W., Goldsmith, R. E., \& Pan, B. (2008). Electronic word-of-mouth in hospitality and tourism management. Tourism Management, 29(3), 458-468.

Lo, A., Cheung, C., \& Law, R. (2004). Information search behaviour of Mainland Chinese air travelers to Hong Kong. Journal of Travel \& Tourism Marketing, 16(1), 43-51.

Loker-Murphy, L., \& Pearce, P. L. (1995). Young budget travelers: Backpackers 
How do Motivation, Pre-Visit Information Search and Destination Image affect Post-Visit Behavioural Intention? The case of an island destination.

in Australia. Annals of Tourism Research, 22(4), 819-843.

Macinnis, D. J., and B.J. Jaworski (1989). Information processing from advertisements: Towards an integrative framework. Journal of Marketing, 53, 123.

Medhekar, A., \& Newby, L. (2011). Information search to travel abroad for medical treatment. International Handbook of Academic Research and Teaching, Vol/lss 1-12.

Moorthy, S., Ratchford, B. T., \& Talukdar, D. (1997). Consumer information search revisited: Theory and empirical analysis. Journal of Consumer Research, 23(4), 263-277.

Moutinho, L. (1987). Consumer behaviour in tourism. European Journal of Marketing, 21(10), 5-44.

Mules, T., Pforr, C., \& Ritchie, B. W. (2007). The impact of domestic tourism on perceptions of Australia's national capital. Journal of Travel \& Tourism Marketing, 22(3-4), 35-53.

Murphy, L., Benckendorff, P., \& Moscardo, G. (2007). Linking travel motivation, tourist self-image and destination brand personality. Journal of Travel \& Tourism Marketing, 22(2), 45-59.

Pearce, P. L., \& Lee, U. I. (2005). Developing the travel career approach to tourist motivation. Journal of Travel Research, 43(3), 226-237.

Pike, S. (2002). Destination image analysis-a review of 142 papers from 1973 to 2000. Tourism Management, 23(5), 541-549.

Prayag, G. (2012). Paradise for who? Segmenting visitors' satisfaction with cognitive image and predicting behavioural loyalty. International Journal of Tourism Research, 14(1), 115.

Priporas, C. V., Vassiliadis, C. A., \& Stylos, N. D. (2012). Qualitative findings on marketing management practices from Greek ski centers. Qualitative Market Research: An International Journal, 15(4), 385-403.

Romanazzi, S., Petruzzellis, L., \& lannuzzi, E. (2011). "Click \& experience. Just virtually there." The Effect of a
Destination Website on Tourist Choice: Evidence from Italy. Journal of Hospitality Marketing \& Management, 20(7), 791-813.

Sarma, M. K. (2007). Influence of information sources on tourists: a segment-wise analysis with special focus on destination image. Vision: The Journal of Business Perspective, 11(1), 35-45.

Schiffman, L. G., \& Leslie, L. K. (2000). Consumer Behaviour (7 ed.). New Jersey: Prentice-Hall.

Sirakaya, E., \& Woodside, A. G. (2005). Building and testing theories of decision making by travellers. Tourism Management, 26(6), 815-832.

Sparks, B. (2007). Planning a wine tourism vacation? Factors that help to predict tourist behavioural intentions. Tourism Management, 28(5), 1180-1192

Stronza, A. (2007). The economic promise of ecotourism for conservation. Journal of Ecotourism, 6(3), 210-230.

Stylos, N., \& Andronikidis, A. (2013). Exploring the Cognitive Image of a Tourism Destination. TOURISMOS: An International Multidisciplinary Journal of Tourism, 8(3), 77-97.

Su, M. M., \& Wall, G. (2009). The QinghaiTibet railway and Tibetan tourism: Travelers' perspectives. Tourism Management, 30(5), 650-657.

Tham, A., Croy, G., \& Mair, J. (2013). Social media in destination choice: Distinctive electronic word-of-mouth dimensions. Journal of Travel \& Tourism Marketing, 30(1-2), 144-155.

Thapa, B., Graefe, A. R., \& Absher, J. D. (2002). Information needs and search behaviours: A comparative study of ethnic groups in the Angeles and San Bernardino National Forests, California. Leisure Sciences, 24(1), 89-107.

Um, S., Chon, K., \& Ro, Y. (2006). Antecedents of revisit intention. Annals of Tourism Research, 33(4), 1141-1158.

Vassiliadis, C. A., Priporas, C. V., \& Andronikidis, A. (2013). An analysis of visitor behaviour using time blocks: A study of ski destinations in Greece. Tourism Management, 34, 61-70.

Wang, D. (2004). Hong Kongers' cross-border consumption and shopping in 
Shenzhen: patterns and motivations.
Journal of Retailing and Consumer Services, 11(3), 149-159.

Xiang, Z., \& Gretzel, U. (2010). Role of social media in online travel information search. Tourism Management, 31(2), 179-188.

Yuan, J. J., Morrison, A. M., Cai, L. A., \& Linton, S. (2008). A model of wine tourist behaviour: a festival approach. International Journal of Tourism Research, 10(3), 207-219.
Žabkar, V., Brenčič, M. M., \& Dmitrović, T. (2010). Modelling perceived quality, visitor satisfaction and behavioural intentions at the destination level. Tourism Management, 31(4), 537-546.

Zins, A. H. (2007). Exploring travel information search behaviour beyond common frontiers. Information Technology \& Tourism, 9(3-4), 149-164.

Yuan, S., \& McDonald, C. (1990). Motivational determinates of international pleasure time. Journal of Travel Research, 29(1), 42-44. 